\title{
Teaching and Learning Activities in Classroom and Their Impact on Student Misunderstanding: A Case Study on Negative Integers
}

\author{
Nyiayu Fahriza Fuadiah \\ Departement of Mathematics Education, Universitas PGRI Palembang, Indonesia, \\ fahrizafuadiah@gmail.com

\section{Didi Suryadi} \\ Prof., Departement of Mathematics Education, Universitas Pendidikan Indonesia, \\ Indonesia, ddsuryadil @gmail.com

\section{Turmudi} \\ Prof., Departement of Mathematics Education, Universitas Pendidikan Indonesia, \\ Indonesia,turmudi@upi.edu
}

This study is a series of Didactical Design Research in prospective analysis stage to comprehensively identify some obstacles in learning negative integer in order to capture how the learning process used by teachers and how the impact on students in understanding the concept of negative numbers. This research is a case study administered to seventh-grade students in one of the classes in a junior secondary school in Indonesia to investigate how the teacher managed the learning process of integers and identify students' thinking construction. Involving a mathematics teacher and 37 students, this qualitative study collected data from field observations, interviews and document review. The data were analyzed by the perspectives of learning obstacles based on Theory of Didactical Situation. Findings show how teacher describes the negative integers and the arithmetic concepts to the students and its contribution in causing misunderstanding on the students. Within the framework of epistemological obstacles, the result of this study is used as a basis for designing a learning program which can overcome problems related to teaching and learning of negative integers.

Keywords: teaching, learning, mathematics teachers, negative integers, students misunderstanding, structure of thinking

\section{INTRODUCTION}

Integers are the first type of number that students have to learn and it requires logic as they have to figure out a number less than zero without concrete modeling (Stephan \&

Citation: Fuadiah, N. F., Suryadi, D., \& Turmudi (2019). Teaching and Learning Activities in Classroom and Their Impact on Student Misunderstanding: A Case Study on Negative Integers. International Journal of Instruction, 12(1), 407-424. https://doi.org/10.29333/iji.2019.12127a 
Akyuz, 2012). Integers and integer operations are one of the difficulties often encountered by the students in mathematics learning (Kilham, 2008; Vlassis, 2004). Most of the problem is the arithmetic operations involving negative integers. Negative integers are advanced lessons after students recognize positive integers. The material of integer operation is an arithmetic skill that students should have learned; which serves as the basis for their learning of next important application, algebra (Tall, 2001). In this line, Seng (2012) argues that the ability to manipulate integer is the basic skill required in solving algebraic expression. This skill belongs to arithmetic manipulation of negative number. Therefore, understanding the concept of arithmetic operation involving negative number is essential to be taught to students in their learning process. In turn, negative integers (negative numbers) and operations with signed numbers can be learned more meaningfully when taught within an algebrafied curriculum (Peled \& Carraher, 2006)

In Indonesia, negative integers are introduced to fourth-grade elementary students after they have learned whole number and its arithmetic operation in the previous year (Ministry of Education and Culture, 2013). Studies related to negative numbers have shown that the main problem many students experience in learning integer operation is understanding negative number due to its abstract nature (Altiparmak \& Ozdogan, 2010; Blair, Rosenberg-Lee, Tsang, Schwartz, \& Menon, 2012; Bishop et al., 2014; Larsen, 2012; Heeffer, 2011). Besides, students' learning experience at primary school also influences their comprehension of this concept. Bofferding (2010) stated that a brief and quick insufficient introduction to negative numbers at primary school leads to students' difficulty when learning integer operation due to their insufficient learning of this topic. Considering its importance in determining students' achievement, students' learning process, which is the most essential part of teaching activities, has a significant role in their understanding of certain concepts (Schmidt, 1997). To improve students' comprehension, teachers often use contexts so that students can synergize it with the topic they are learning. However, without sufficient comprehension of mathematical content, the improper use of contexts will only lead to an example of application (Suryadi, 2013). In his opinion, when the context is only used as sample application, students will only copy the procedures shown by their teacher without proper comprehension. When facing different situations, students will find difficulties in completing the assigned tasks, and this phenomenon is called learning obstacles.

A few short preliminary interviews with three mathematics teachers in three different junior secondary schools show that integer operation poses certain obstacles to both students and teachers. Various studies indicate that many students still make mistakes in completing integer operation. Whitacre et al. (2011) stated that students often have problems in conceptualizing integer and its arithmetic operation. They argued that students do not find obstacles when they learn integer arithmetic operation. The problems start when students involve negative numbers in integer operation (Bishop et al., 2014; Fuadiah, Suryadi, \& Turmudi, 2017). Various methods and strategies with different contexts have been tried out but the results are not satisfactory yet. As teachers reported, the impact of this problem continues when discussing topics of higher level. Having experienced this problem, teachers started to feel worried, given the importance 
of students' mastery of the topic before they move onto algebra (Seng, 2012; Vlassis, 2002). This idea is also supported by Schmidt (1997) who argued that students have to have good grasps of relevant concepts before moving to its related application.

Many studies revealed the student's difficulties experience in negative integers and the others described the design of learning as the solution of learning problems associated with negative integers to improve students' understanding. However, identifying the root of the obstacles or problems is the best solution. Explore how teachers teach can give you an idea of how a concept presented at the students and how it impacts the students' understanding. Based on this condition, this study focused on teachers' activities in the classrooms, how they teach, and what concepts they develop in their students as well as its implication on students' comprehension. As such, this study explored the obstacles that students and teachers face in the classroom. The findings of this study are expected to answer the questions of how the learning process of negative number influences students' comprehension. Thus, this study is expected to find solutions that will minimize the learning obstacles associated with negative integers.

\section{CONTEXT AND REVIEW OF LITERATURE}

Negative numbers are always an interesting topic to discuss, especially from a didactical of mathematics point of view (Thomaidis, 1993). Many studies have shown how students experienced some difficulties to understanding the concept of negative numbers. Based on students' difficulties, Vlassis (2004) suggest that the minus sign plays a major role in the development of understanding and using negative numbers. Vlassis (2008) proposed three level conceptualizations of negative numbers that are further elaborated in the nature of a minus sign. This level includes interpreting minus as a binary, symmetric, and unary function. Based on this, Lamb et al. (2012) explained three meanings of minus sign (see Table 1).

Table 1

Meaning of minus sign (Lamb et al., 2012)

\begin{tabular}{ll}
\hline \multicolumn{1}{c}{ Problem } & Meaning of the Minus Sign \\
\hline $1.5-8=\square$ & Subtraction (a binary operation) \\
\hline $2 . \square+5=-2$ & $\begin{array}{l}\text { Symbolic representation for a negative number (sign } \\
\text { number) }\end{array}$ \\
\hline 3. Which larger, - -4 or 4? & The opposite of (a unary operation) \\
\hline
\end{tabular}

The three problems use symbol "-" that we call, in general, as minus sign. However, each problem can generate different meanings for students. In Problem 1, the minus sign indicates a subtraction (binary operation, or function with two operands exactly), whereas in Problem 2, the minus sign is part of the symbolic representation for the negative numbers. The binary nature of the minus sign corresponds to the subtraction operation (e.g. $7-4=3$ ). With negative numbers, the binary interpretation is also associated with a reduction changes meaning as addition when subtracting with negative numbers (Bofferding, 2010). In Problem 3, the minus sign first might be considered the opposite of (unary operator, or function with one operand exactly) so that people can read - (-4) as "the opposite of negative four" than is often read by students in general as 
a "negative negative four". Interpretation of this opposite of is the right way to formulate a minus sign, but for some students, including high school students, it seems still to hold the concept - (-4) as a "negative negative four". Bofferding (2014) used the term "minus" refers to the symbol "-", "subtraction sign" refer to the binary meaning of the minus sign, and "negative sign" refer to unary meaning of the minus sign. Finally, unary nature of the minus sign in line with the original idea of negative numbers as a new form of numbers located to the left of zero on the horizontal number line, with decrease in the number moving away from zero.

The minus sign that attached to a number makes the number to be a negative number. This number can be represented on the number line as the direction of the opposite of positive number, i.e. the number on the right from zero (on the horizontal number line) or at the bottom of the zero (on the vertical line number, has a quantity value less than zero (Heffer, 2011; Altiparmak \& Ozdogan, 2010). In the daily context, negative numbers can be represented as profit and costs, property and debt, win and loss score, and so on (Stephan \& Akyuz, 2012; Sreffland, 1996).

Related to function of the minus sign as the meaning of negative numbers, there are three dimensions of the concept of negative numbers proposed by Altiparmak \& Ozdogan (2010), namely 1) the negative case that focuses on the meaning of a number, direction, and the quantity of numbers (numerical system), 2) the meaning of the calculations and number line that focuses on arithmetic operations that connect between what has understood in the real world and the use of the number line as illustrate the context of a situation concretely, and 3) interpretation and explanation, namely how students make to understand the relationship negative numbers with a context, interpret, generalize, define count operations, and relate a context to another context.

\section{METHOD}

The whole of this research is Didactical Design Research (DDR) which has three stages; prospective, metapedadidactic, and retrospective analysis (Suryadi, 2013). This study focused on prospective analysis that is studying learning obstacles in aspects of learning design that take place in the classroom. Learning obstacles themselves are by ontogenic, epistemological, and didactic obstacles (see Brousseau, 2002 p.86). DDR explores the learning design characteristics used by the teacher and their impact on the process and development of children's thinking. Based on this, the study to reveal the variety of thought processes and various obstacles related to them is an important part of DDR. To identify learning obstacles, in addition to diagnosing students 'understanding, we feel the need to reveal how the learning design is applied by the teacher in the classroom and its effect on students' understanding of negative integers. Therefore, this study involved high school students and mathematics teachers as participants in this study.

\section{Participants}

The participants in this study were selected by purposive sampling.Three mathematics teachers from three different junior secondary schools expressed their willingness to be observed during their teaching of integer operation sessions. These teachers have been teaching mathematics for about 5-20 years and relevant educational backgrounds of 
mathematics education. The study also involved 96 students of year seven who sit in three different classes as total participants. The subject of the study is one female mathematics teacher and her 37 students, assuming that students in the other two classes have similar learning processes. Observation was conducted for two sessions of introduction to integer and integer operation. Each session lasted for $2 \times 40$ minutes with non-participation and non-treatment method.

\section{Data Collection Tools and Data Analysis}

Data in this study were collected from interviews, field observations, and document review. Interviews were conducted on students to explore the extent to which they understood the subject matter, field observations were carried out through video recordings of the classroom learning process in the classroom and students' discussions in small groups, and reviewing documents in the form of student answers given in writing, textbooks that the teacher used, and field notes. All data are analyzed by series of events through reduction the data. The analysis of videos of learning process and students' interactions in the classroom was based on students' thinking structures and their relation to the concepts delivered by the teacher. The results of the analysis are presented in a narrative method.

\section{Validity and Reliability of the Study}

To obtain good quality, this research analyzes the validity of the research through qualitative research perspectives that is trustworthiness (Denzin \& Lincoln, 2005) and reliability refers to the quality of the research itself (Sarosa, 2012). The belief of this study is viewed from four things, as follows:

1. Credibility. Strategy that is in line with the credibility criteria that become the reference in this research, that is: (a) Triangulation was done to see the relation obtained from various sources that is written document in the form of field notes, student work result, and audiovisual record; (b) Member checking to conduct followup interviews to participants and give them a chance to comment on the results of the study. In this study, the results of identification of learning obstacles will be informed back to the students as a reflection for students, teachers, and researchers;(c) Researchers clarified the bias by doing self-reflexology and creating an open and honest narrative; and (d) Peer de-briefing which conducted discussions with colleagues who can review the research so that obtained views or other interpretations that can enrich the validation of research.

2. Transferability. The strategies used that allow the transfer of findings into other contexts are detailed analysis of interview transcripts, observation and document notes, the use of theory and purposive sampling, and the logical presentation and theoretical concise propositions accompanied by relevant examples of the data. In this study, the learning activities regarding negative integers and interaction between teachers and students was described in detail each meeting are presented in descriptive and reinforced with written or unwritten documentation. 
3. Dependability. In this study external auditors need to do to get an objective assessment, the accuracy of research data, level of data analysis, and matters relating to the relationship of problem formulation and data involving teachers and lecturers of mathematics education.

4. Confirmability. Confirmability can be expressed as the extent to which research results are based on research objectives and not subject to change caused by bias. For that the researcher makes the research process as transparent as possible by clearly describing how data is collected, the procedures undertaken during the study, analyzed, and the theory.

\section{FINDINGS AND DISCUSSION}

Overall, the learning process was divided into two sessions; introduction to integer and integer operation. These learning processes refer to the Indonesian National Curriculum of 2013 which the participating schools have implemented. The purpose of introducing the concept of integer operation is to complete the integer operation of addition and subtraction as well as to identify the characteristics of integer operation. The focus of the study is the integer operation of addition and subtraction which includes negative number. The description below describes how teachers manage the classroom and the process transfers of knowledge from the teacher to the students.

\section{Forward for positive and backward for negative}

The introduction of integer and the meaning of negative number took place in one session. Overall, the learning process consisted of three sections; pre-activity, main activity, and post-active. Here we report and describe the main activities. Based on observations and video recordings, the stage of knowledge transfer from teacher to students occurs (Table 2). 
Table 2

The learning process of integer introduction and the meaning of negative number

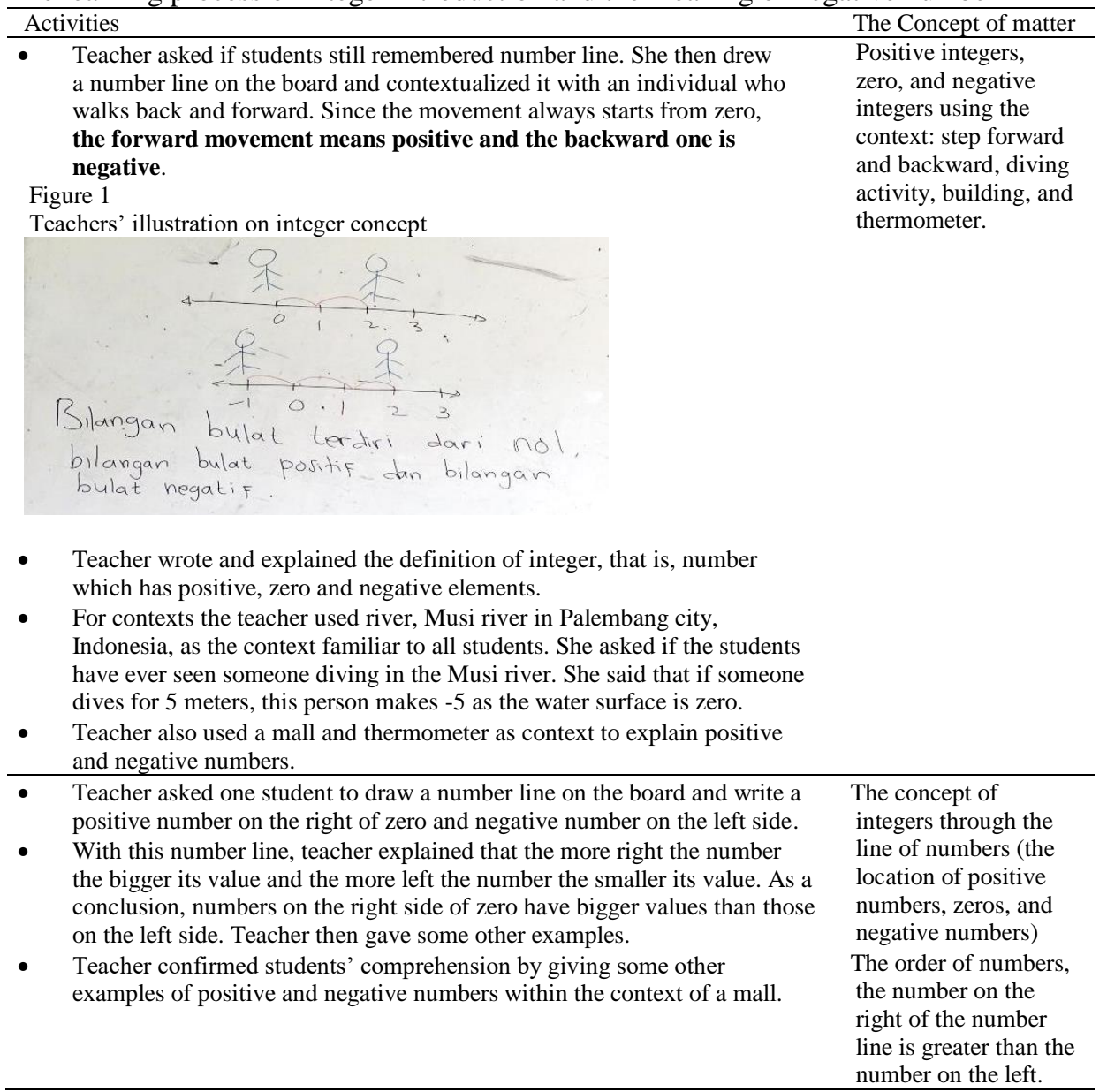

Forward and backward movements (if moving forward is positive and if moving backwards is negative on Table 2) was done by describing a number line with a forward movement to the right of the number line (a positive integer) and a backward movement towards the left (a negative integer). This example can give the meaning that backward is the opposite direction by advancing so that the teacher explicitly wants to explain that negative numbers are the opposite of positive numbers but we certainly know that the step forward is not to the right and step back not to the left. This method can prevent students to explore that negative numbers do not only have a leftward direction. 
One of the tasks assigned to the students is to determine the number using the number line. The majority of the students used number line as contexts to complete other questions, as shown below.

Using number line, determine

a. Five integers located on the left side of 3 ;

b. Six integers located on the right side of -2 ;

c. Four integers which are more than -1;

d. Seven integers which are less than 5;

Almost all students answered this question with one, instead of a series number. For example, for question a, they only answered -2 , instead of $-2,-1,0,1$, and 2 .

If the biggest number is negative, the result is negative and if the biggest number is positive, the result is also positive

The topic of the second session was the integer operation for addition and subtraction. Similar to the previous session, the learning process also had three stages; pre, main, and post activities. How the main activity process takes place can be seen in Table 3 below.

Table 3

The learning activities of operation of integer

\begin{tabular}{|c|c|}
\hline Activities & The concept of matter \\
\hline $\begin{array}{l}\text { - The first learning materials discussed was integer operation with horizontal } \\
\text { number line. For example, teacher wrote } 6+(-8)=\ldots \text { as example, then } \\
\text { drew a number line on the board and explained that number line always } \\
\text { starts with zero. } \\
\text { Teacher wrote }(-3)+(-4)=\ldots \text { and offered students to work the exercise. A } \\
\text { student came forward and did the task, obtaining }-7 \text { as the answer. }\end{array}$ & $\begin{array}{l}\text { Doing the arithmetic } \\
\text { operation using the } \\
\text { number line as a tool. } \\
\text { The negative number } \\
\text { moves to the left and } \\
\text { the positive number } \\
\text { moves to the right. }\end{array}$ \\
\hline $\begin{array}{l}\text { - Teacher explained the non-aided integer operation using debt or loan as } \\
\text { context since students have learned it at primary school. Teacher imagined } \\
-4+5 \text { as money loan } 4 \text { paid by } 5 \text { which leaves } 1 \text {. } \\
\text { Teacher said that loan can be used as context in integer operation or other } \\
\text { contexts that students can understand and yield correct answer. }\end{array}$ & $\begin{array}{l}\text { Arithmetic operation } \\
\text { without tools by using } \\
\text { debt as context. } \\
\text { Borrow is presented } \\
\text { as a negative number } \\
\text { and pay is represented } \\
\text { as a positive number }\end{array}$ \\
\hline $\begin{array}{l}\text { - Teacher introduced other methods of integer operation with different signs } \\
\text { by looking at the sign in the bigger number subtracted by a smaller } \\
\text { number. } \\
\text { - Teacher emphasized that students can choose the easiest method. } \\
\text { - Some students did the exercises teachers wrote on the blackboard; } 23+19 \\
=\ldots,(-42)+27=\ldots, 38+(-53)=\ldots,(-27)+(-14)=\ldots .\end{array}$ & $\begin{array}{l}\text { Addition by paying } \\
\text { attention to the sign of } \\
\text { number. }\end{array}$ \\
\hline $\begin{array}{l}\text { - A student asked a question with three integer operations. } \\
\text { - Teacher wrote }(-34)+(46)+(-28)=\ldots \text { and then called upon a student to } \\
\text { answer. With the teacher's direction, the student first subtracted } 34 \text { from } \\
46 \text {, the result was subtracted by }-28 \text {. The obtained result is }-16 \text {. } \\
\text { - Teacher asked students to do similar exercises from the textbook. Students } \\
\text { worked in some small groups. }\end{array}$ & $\begin{array}{l}\text { Exercises and } \\
\text { assignments }\end{array}$ \\
\hline
\end{tabular}


The interesting findings that we got from learning activities in Table 3 was the integer operating rule proposed by the teacher by looking at the sign on a bigger number; bigger numbers are always subtracted by smaller one. This technique indicated that if a bigger number is negative then the result will be negative and if the bigger number is positive then the result is also positive. This procedure is given by the teacher to make it easier for students to determine the results of integer operations in numbers with larger digits. In fact, this procedure only applies to operations on only two numbers so that it does not apply to operations on three or more numbers. Regardless of this, many students still preferred to use horizontal number lines when completing integer operation exercises.

\section{The subtraction involving negative integers}

The next lesson after the addition was the subtraction of integers. Based on our observation, this material was quite difficult for teacher to explain the concept and on the other hand, it was quite difficult for students to understand it. Main activities description describes in Table 4.

Table 4

The main learning activities in subtraction of integers

\begin{tabular}{|c|c|}
\hline Activities & The concept of matter \\
\hline $\begin{array}{l}\text { The teacher continues the lesson with integer subtraction operations } \\
\text { material, then she wrote: } \\
8-4=4 \\
4-8=\ldots \\
-4-8=\ldots \\
\text { A student writes }-4 \text { as a result of } 4-8 \text {. The teacher suggested using a } \\
\text { number line. Another student came forward and used the number line to } \\
\text { solve the problem }-4-8 \text { and got the result }-12\end{array}$ & $\begin{array}{l}\text { Subtraction using the } \\
\text { number line as a tool. } \\
\text { Minus mean moving } \\
\text { to the left on the } \\
\text { number line. }\end{array}$ \\
\hline $\begin{array}{l}\text { - Teacher asked how about }-4+(-8) \text {. Using the number line, it is found } \\
\text { that }-4+(-8)=-12 \text {. } \\
\text { Teacher said that }-4-8=-4+(-8) \text {. The teacher involved students to } \\
\text { make conclusions by discussing. }\end{array}$ & $\begin{array}{l}\text { One of the nature of } \\
\text { operations is } \mathrm{a}-b=a \\
+(-b)\end{array}$ \\
\hline $\begin{array}{l}\text { - Teacher wrote }-4-(-8)=\ldots \text { and }-4+8=\ldots \\
\text { - A student tried to calculate }-4-(-8) \text { by using the number line. After } \\
\text { making a line from } 0 \text { to }-4 \text {, the student looked confused and thinking. } \\
\text { Then he created a line above }-4 \text { to }-12 \text { and wrote }-12 \text { as a result. } \\
\text { - The teacher corrected by making the } 8 \text {-step line to the right of }-4 \text { and } \\
\text { writing- }(-8) \text { above the line then drawing a line from } 0 \text { to } 4 \text { as a result. } \\
\text { The teacher explained that the opposite of the negative is positive so } \\
\text { that's why she made the line to the right because - }(-8) \text { means the } \\
\text { opposite of }-8 \text { thus becoming } 8 \text {. } \\
\text { - The teacher asks the students to conclude, then write }-4-(-8)=-4+8 \text {. }\end{array}$ & $\begin{array}{l}\text { Subtraction involving } \\
\text { negative numbers, the } \\
\text { transformation of } a- \\
(-b) \text { becoming } a+b\end{array}$ \\
\hline
\end{tabular}

We found that it was difficult for students to accept that $-(-8)$ to +8 , because the way the previous teacher delivered was if the minus sign then moved to the left and if reduced moved to the left also. But now they found that subtract with the minus sign instead move to the right. Up here, the new knowledge they get is that subtract with a minus sign will be a positive sign. 


\section{Students' comprehension}

In this section, we want to explain and illustrate how students understanding what they have then after the learning. To find out the extent to which students comprehend the learning materials, they were given some exercises in integer operation of addition and subtraction with negative numbers. Some students used debt for contexts, as teacher has taught before, as shown by Dina (See Figure 2 below)

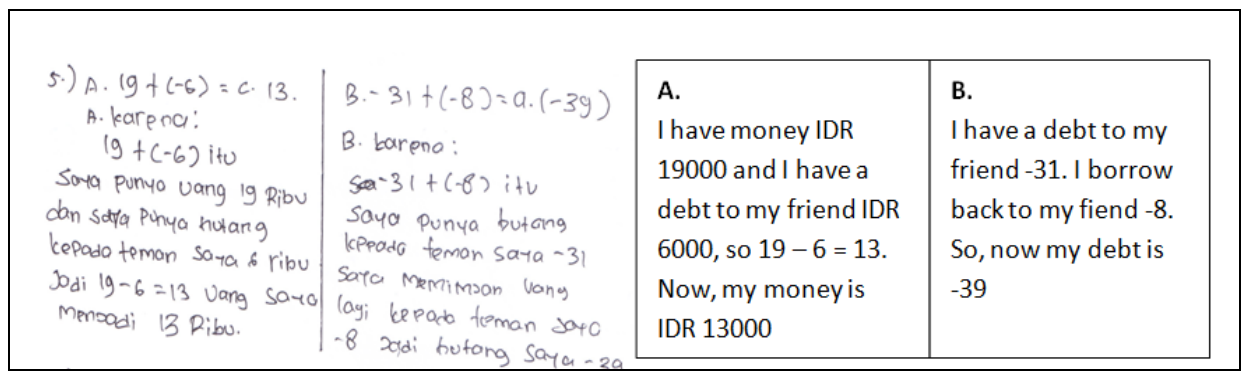

Figure 2

Dina's answer

Dina could answer each question of integer operation correctly by imagining negative number as loan. Many students used this technique as often explained by their teachers. Figure 3 shows the thinking structure of Dina who used loan money as analogy.

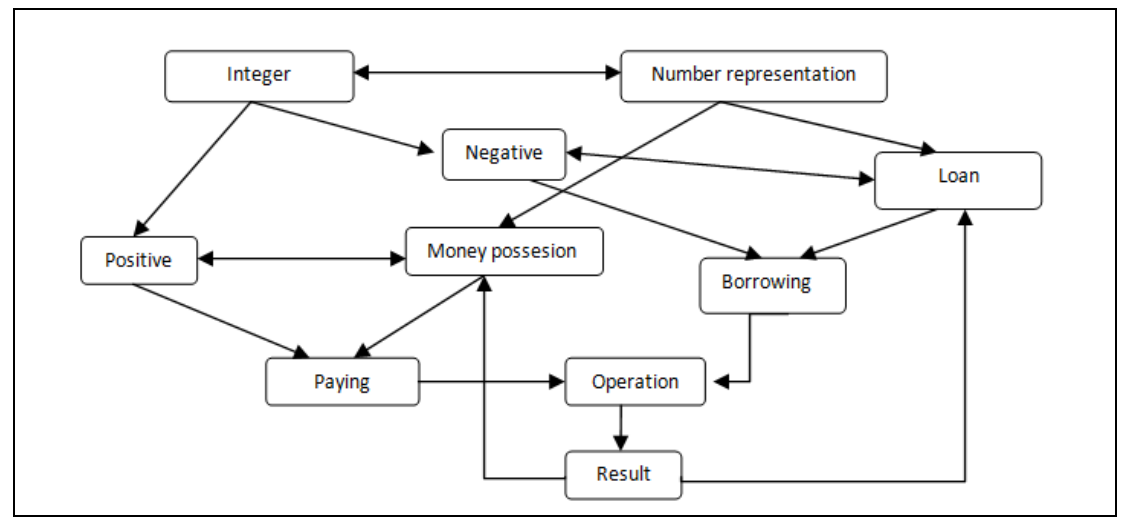

Figure 3

Dina's thinking process by representing negative number as loan 
Another answer was put forward by giving a sign for each number followed by an analogical concept of integer operation of multiplication (See Figure 4).

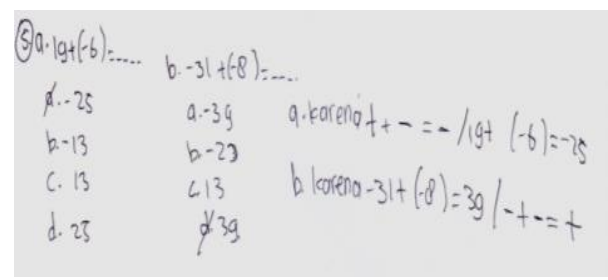

Translate:

$19+(-6)=-25$, because + plus $-=-$ so that $19+(-16)=25$

$-31+(-8)=39$, because $-31+(-8)=$ 39 from - plus $-=+$

Figure 4

Anita's answer

Anita's answer for $19+(-6)$ is 25 , assuming that the addition of positive and negative numbers yields negative number. Another answer for $-31+(-8)$ is 39 , based on the assumption that the addition of two positive numbers yields positive result. Anita's thinking structure is described in Figure 6.

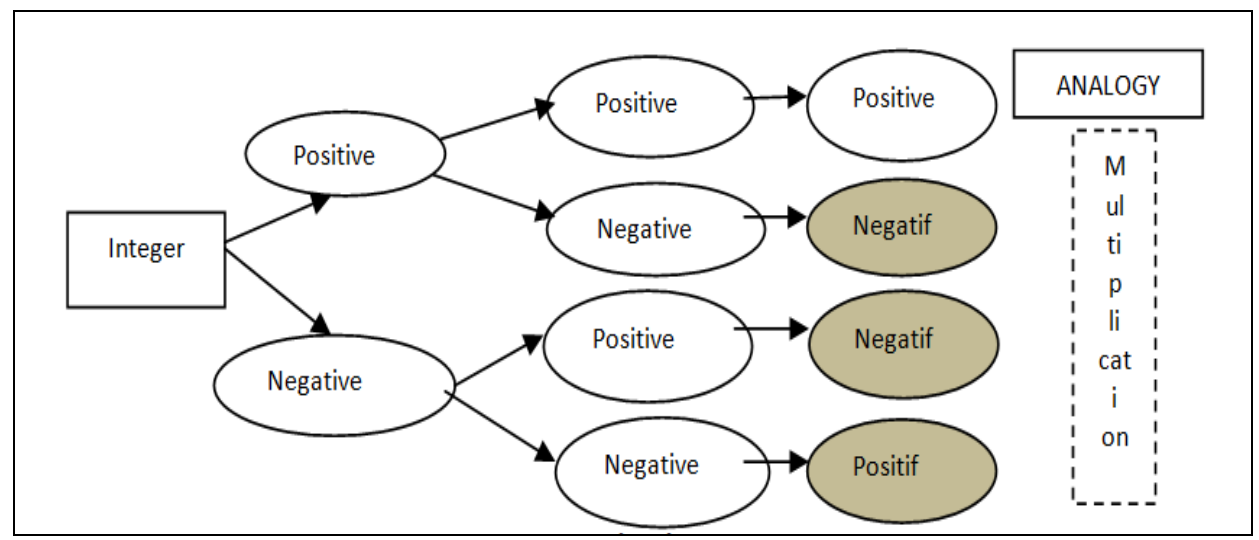

Figure 5

Anita's thinking structure in integer operation

Another answer with different concept is also shown by another student (See Figure 6). 


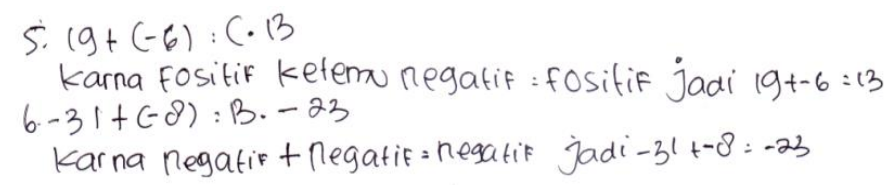

Figure 6

A concept used by Luthfi in completing integer operation

Translate:

$19+(-6)=-13$

Because positive with negative become to be positive, so that $19+(-6)=-13$

$-31+(-8)=-23$

Because negative + negative $=$ negative, so that $-31+-8=-23$

Based on his answer and reasoning, Luthfi has the concept that if positive number is added to negative one, the result is negative and the addition of two negative numbers is negative. The misunderstanding that occur to him are similar to Anita but in a slightly different way. Based on Figure 6, it is concluded that for Luthfi, the addition of two negative numbers can be represented as subtraction operation $a-b$, whereas $a$ and $b$ are considered positive numbers. Therefore, he answered $19+(-6)=19-6=13$ and $-31+$ $(-8)=31-8=-23$ (23 changes into -23 as he believes that negative plus negative equals negative).

\section{Teaching and learning analysis and the contributions for students misunderstanding}

The problem of low math skills is not something newly discussed. One reason is that students do not learn math concepts in depth at higher cognitive levels because they only memorize it (Shivani, 2015). We also found this in learning observation when the teacher delivered a memorized procedure such as the number line; Negative numbers always have a right direction while negative numbers always go left (See Table 2). This can result in the limitations of students' point of view towards the direction of numbers themselves. As the meaning of the opposite number, negative numbers have the opposite direction of positive numbers and positive numbers themselves can have a direction anywhere, in a three-dimensional perspective.

The learning on Table 3, the teacher made a straightforward rule of operation: subtract the bigger number with the smaller one and then add sign $(-$ or + ) following the bigger number. The provision of this rule is too early and quick, without sufficient exercises and exposure so that students' comprehension of the concept is not really comprehensive. Context relevance-based learning experience can motivate students to apply their mathematics knowledge in more relevant contexts in both real life and future workplace (Turmudi, 2009). As such, every knowledge and skill that students acquire 
should come from their ability to match knowledge with real life situations (Brousseau, 2002 p.23).

In addition, several observations also show that the role of teacher is still dominant in the learning process. The teacher directly helped students complete the exercises of integer operation. Consequently, students become more dependent and can only complete the given tasks with the assistance of the teacher. This is caused by a distance between teacher's explanation and students' comprehension due to insufficient adaptation process. According to the Theory of Didactical Situation, to improve students' autonomy, the adaptation process through by the student will develop optimally with the teacher's adidactical action, that is, giving students an opportunity to be more autonomous learners by providing a supportive milieu of independent learning without direct intervention (Artigue, Haspekian, \& Corblin-Lenfant, 2014; Brousseau, 2002; Manno, 2006; Perrin-Glorian, 2008; Ruthven, Laborde, Leach, \& Tiberghien, 2009). The didactical situation, argued by Laborde and Perrin-Glorian (2005), is designed to minimize the involvement of teacher in the learning process. To complete the assigned exercises, students should independently work on their own, by employing their previous knowledge on the topic, so that they can solve the given problems. The interaction between students and their supporting milieu is both a consequence and source of knowledge. Milieu-based students' activities mean that they receive new information and feedback which needs to adjust to their previous knowledge. When it happens in a stable condition, this adjustment can lead to the development of students' new knowledge.

Analysis of students' learning process shows that most students do not have problems comprehending minus sign for subtraction and as a symbol of negative number. The problem starts when they come to integer operation, particularly when handling certain operations like $a-(-b)$. The learning in Table 3 , the teacher analogized negative number as 'loan' or 'borrowing' to help students think negative number more vividly. This concept is used by many students and seems to be effective in solving their problems (see Figure 2 and 3). A similar phenomenon was found by Subanji (2015, p.59) in his study on students' problems in integer construction. A student believes that the operation of $-4-3=-7$ is correct since 'someone has a loan (4) and then borrows again (3) so that the total of his/her loan is -7 . There is a wrong process in constructing the concept of integer operation, which is to equate the meaning between the symbol of number and operation of the number in the symbol "-" (minus). There is a wrong process in constructing the concept of integer operation, which is to equate the meaning between the symbol of number and the symbol of operation on the symbol "-" (minus). Believing that 'negative and negative means positive', students who construct $-4-(-3)=$ -1 come with $-4-(-3)=-4+3$. The analysis shows that these students consider both minus symbols in $-(-3)$ similar. In fact, the first minus symbol is a subtraction operation whereas the second one is a negative number. Based on this phenomenon, it is concluded that mistake committed in this area is caused by confusion in differentiating between the minus symbols for subtraction operation and a negative number. This finding shows a misunderstanding of the concepts that occur in students. In this case, the students can come with the correct answer but incorrect reasoning (Subanji, 2016). 
Students have different comprehensions of 'negative and negative means positive' concept (see Table 4). As Figure 6 shows, students analogize the rule of multiplication with addition, so that the result of $19+(-6)$ equals -25 , based on the assumption that 'positive and negative means negative'. Similarly, they believe that $-31+(-8)$ equals 39 assuming that 'negative and negative means positive. This confusion shows that teacher's explanation of $-(-a)$ equals $+a$, has developed into a misleading thinking structure in arithmetic operation. In her study, Bellamy (2012) concludes that the biggest challenge in introducing negative number does not lie in expanding the number system but in redefining the four basic operations: addition, subtraction, multiplication, and division. In her opinion, students should be exposed more to be correct understanding of arithmetic number than relying on the formula that 'two minuses mean plus'.

Based on the findings on the students' thinking process there has been a misunderstanding that occurs due to a misperception of the concept conveyed by the teacher. Submission of concepts that are limited to one context only prevents students from developing their thinking in a more complex context, for example the use of number line or loan as the only model in the operation of calculating negative integers prevents students to developing their reasoning in more complex operations. Mental activities that encourage appropriate concepts can help students improve their understanding of the meaning of negative integers. In line with this, Duval (2006) stated that what concerns mathematical activity is pushed back into the background or explained either by conceptual understanding (or misunderstanding) or by a common pedagogical framework about the importance of student' activity and the role of their mental representations for comprehension.

Finally, Bishop et al. (2011) recommend teachers to develop ways by which they can enrich and extend students' knowledge of mathematics by developing their ideas about negative numbers during classroom interaction. In other words, learning must develop and explore students' potentials. Student-centered learning is believed to produce a number of benefits for students, including higher levels of engagement, increased confidence, and better behavior (Burns, Pierson, \& Reddy, 2014). In this case, it is important to note that successful instructional intervention will be benefit students in exploring the use of similar instruction in upper levels. Besides, it can also provide students with the experience of using integer concept which focuses on different meanings of minus sign as well as interpret the integer value from positive and negative perspectives (Bofferding, 2014).

\section{CONCLUSION}

Based on the abovementioned analysis of classroom learning, the concept taught to students does not provide a clear explanation about minus in subtraction operation and as marker of negative number. The teaching also relies on the use of practical rules or formulas with the initial purpose to help students but finally led to their misunderstanding. Discussion that is an interaction between teacher and students also takes place less than optimal, teacher dominate by conveying knowledge by lecture method. The concept of negative numbers conveyed directly result misunderstanding of the students, and it happens for a long time. Suryadi (2010) elaborated Vygotsky's 
theory that the discussion should be applied to give students the opportunity to optimize their learning process. Such interaction allows teacher and students to share and modify their own way of thinking. In addition, there is also the possibility for some students to display their own arguments as well as for other students to have the opportunity to try to capture other students' thinking patterns. This episode is believed to be able to increase the knowledge and understanding of the objects studied from the previous stage to the higher stages.

Many studies have managed to determine the model of real world and context which can support students' construction of integer. The findings of these studies can be used and developed by teachers and other researchers to design a negative number learning relevant with students' needs and thinking characteristics. The application of didactic situation through its design by teacher during the classroom teaching and learning is expected to be able to develop students' potentials so that they can construct their own targeted knowledge through a series of abstraction process. Action and feedback within a strategy will lead to the construction of new knowledge.

\section{REFERENCES}

Altiparmak, K., \& Ozdogan, E. (2010). A Study on the Teaching of the Concept of Negative Numbers. International Journal of Mathematical Education in Science and Technology, 41(1), 31-47. http://dx.doi.org/10.1080/00207390903189179.

Artigue, M., Haspekian, M. \& Corblin-Lenfant, A. (2014). Introduction to the theory of didactical situation (TDS). In Ahsbahs \& Prediger (Eds.), Networking of theories as a research pratice in mathematics education (pp.47 - 65). Switzerland: Springer International Publishing.

Bellamy, A. (2015). A critical analysis of teaching and learning negative numbers. Philosophy of Mathematics Education Journal, 29. Retrieved from: http://socialsciences.exeter.ac.uk/education/research/centres/stem/publications/pmej/po me29/index.html

Blair, K.P., Rosenberg-Lee, M., Tsang, J.M.., Schwartz, D.L., \& Menon, V. (2012). Beyond Natural Numbers: Negative Number Representation in Parietal Cortex. Frontiers in Human Neuroscience, 6(7), 1-17.

Bishop, J.P., Lamb, L.L., Philipp, R.A., Schappelle, B.P., \& Whitacre, I. (2011). First Graders Outwit a Famous Mathematician. Teaching Children Mathematics, 17(1), 350358 .

Bishop, J.P., Lisa, L.L, Philipp, R.A., Whitacre, I., Schappelle, B., and Lewis, M.L. (2014). Obstacles and Affordances for Integer Reasoning: An Analysis of Children's Thinking and the History of Mathematics. Journal for Research in Mathematics Education, 45(1), 19-61.

Bofferding, L. (2010). Addition and Subtraction with Negatives: Acknowledging the Multiple Meanings of the Minus Sign. In Proceedings of the 32nd annual meeting of the 
North American Chapter of the International Group for the Psychology of Mathematics Education (Vol. 6, pp. 703-710).

Bofferding, L. (2014). Negative Integer Understanding: Characterizing First Graders' Mental Models. Journal for Research in Mathematics Education, 45(2), 194-245.

Brousseau, G. (2002). Theory of didactical situation in mathematics. Kluwer Academic Pulishers.

Burns, M., Pierson, E., \& Reddy, S. (2014). Working Together: How Teachers Teach and Students Learn in Collaborative Learning Environments. International Journal of Instruction, 7(1), 17-32.

Creswell, J.W. (201a). Qualitative inquiry and research design chosing among five approaches. USA: Sage.

Denzin, N.K. \& Lincoln, Y.S. (2009). Menempatkan bidang. (Tranlator by Dariyatno). In Denzin, N.K. \& Lincoln, Y.S (Eds.), Handbook of Qualitative Research (pp. 23-25). Yokyakarta: Pustaka Pelajar.

Duval, R. (2006). A cognitive Analysis of Problems of Comprehension in a Learning of Mathematics. Educational Studies in Mathematics, 61(1-2), 103-131.

Fuadiah, N. F., Suryadi, D., \& Turmudi, T. (2017). Some difficulties in understanding negative numbers faced by students: A qualitative study applied at secondary schools in Indonesia. International Education Studies, 10(1), 24-38.

Haynes, A. (2010). The Complete Guide to Lesson Planning and Preparation. London: Continuum.

Heeffer, A. (2011). Historical objections against the number line. Science \& Education, 20(9), 863-880.

Kilhamn, C. (2011). Making sense of negative numbers (Unpublished doctoral dissertation). Department of Pedagogical, Curricular and Professional Studies; Institutionen för didaktik och pedagogisk profession, Sweden.

Laborde, C. \& Perrin-Glorian, M.J. (2005). Introduction Teaching Situation as Object of Research: Empirical Studies within Theoretical Perspective. Educational Studies in Mathematics, 59(1-3), 1-12.

Lamb, L.L., Bishop, J.P., Philipp, R.A., Schappelle, B.P., Whitacre, I., \& Lewis, M. (2012). Developing Symbol Sense for the Minus Sign. Mathematics Teaching in the Middle School, 18(1), 5-9.

Larsen, J. (2012). Epistemological obstacles of negative numbers. Vector: The Official Journal of the BC Association of Mathematics Teachers, 53(2), 56-60.

Manno, G. (2006). Embodiment and a-didactical situation in the teaching-learning of the perpendicular straight lines concept. Doctoral Thesis. Departement of Didactic Mathematics Comenius University Bratislava. 
Ministry of Education and Culture. (2014). Matematika SMP/MTs Kelas VII Semester 1. Jakarta: Kementrian Pendidikan dan Kebudayaan.

Ministry of Education and Culture. (2013). Kompetensi Dasar Sekolah Dasar (SD)/Madrasah Ibtidaiyah (MI) . Jakarta: Kementrian Pendidikan dan Kebudayaan.

Peled, I., \& Carraher, D. W. (2008). Signed numbers and algebraic thinking. In Kaput, J.J., Carraher, D.W. \& Blanton, M.L. (Eds.), Algebra in the Early Grades (pp.303-328). Routledge.

Perrin-Glorian, M.J. (2008). From producing optimal teaching to analysing usual classroom situations development of a fundamental concept in the theory of didactic situations: the notion of milieu. [Online]. Retrieved from: https://www.unige.ch/math/EnsMath/Rome2008/WG5/Papers/PERRIN.pdf.

Ruthven, K., Laborde, C., Leach, J., \& Tiberghien, A. (2009). Design Tools in Didactical Research: Instrumenting the Epistemological and Cognitive Aspects of the Design of Teaching Sequences. Educational Researcher, 38(5), 329-342.

Sarosa, S. (2012). Penelitian Kualitatif, Dasar-Dasar. Jakarta: Indeks.

Seng, L.K. (2012). An Error Analysis of Form 2 (grade7) Students in Simplifying Algebraic Expression: A Descriptive Study. Electronic Journal of Research in Education Psychology, 8(1), 139-162

Schmidt, H.J. (1997). Students' Misconceptions - Looking for a Pattern. Science Education, 81(2), 123-135.

Shirvani, H. (2015). Pre-Service Elementary Teachers' Mathematics Content Knowledge: A Predictor of Sixth Graders' Mathematics Performance. International Journal of Instruction, 8(1), 133-142.

Stephan, M., \& Akyuz, D. (2012). A Proposed Instructional Theory for Integer Addition and Subtraction. Journal for Research in Mathematics Education, 43(4), 428-464.

Streefland, L. (1996). Negative Numbers: Reflections of a Learning Researcher. Journal of Mathematical Behavior, 15(1), 57-77.

Subanji. (2015). Teori Kesalahan Konstruksi Konsep dan pemecahan masalah Matematika. Malang, Indonesia: Universitas Negeri Malang

Subanji. (2016). Teori Defragmentasi Struktur Berpikir dalam Mengkonstruksi Konsep dan Pemecahan Masalah Matematika. Malang, Indonesia: Universitas Negeri Malang.

Suryadi, D. (2010). Menciptakan Proses Belajar Aktif: Kajian dari Sudut Pandang Teori Belajar dan Teori Didaktik. Retrieved 14 November, 2015 from http://didisuryadi.staf.upi.edu/files/2011/06/MENCIPTAKAN-PROSES-BELAJAR-AKTIF.pdf

Suryadi, D. (2013). Didactical Design Research (DDR) dalam pengembangan pembelajaran matematika. Prosiding Seminar Nasional Matematika dan Pendidikan Matematika. Bandung, Indonesia: STKIP Siliwangi. 
Thomaidis, Y. (1993). Aspects of Negative Numbers in the Early 17th Century. Science \& Education, 2(1), 69-86.

Turmudi. (2009). Landasan Filosofis dan Teoritis Taktik dan Strategis Pembelajaran Matematika. Jakarta: Leuser Cipta Pustaka.

Vlassis, J. (2002). The Balance Model: Hindrance or Support for the Solving of Linear Equations with One Unknown. Educational Studies in Mathematics, 49(3), 341-359.

Vlassis, J. (2008). The Role of Mathematical Symbols in the Development of Number Conceptualization: The Case of the Minus Sign. Philosophical Psychology, 21(4), 555570.

Whitacre, I., Bishop, J. P., Lamb, L. L., Philipp, R. A., Schappelle, B. P., \& Lewis, M. (2011). Integers: History, textbook approaches, and children's productive mathematical intuitions. In Proceedings of the 33rd annual meeting of the North American Chapter of the International Group for the Psychology of Mathematics Education (pp. 913-920). University of Reno Reno, NV. 